\title{
The contributions of the hydrogen transition to the goals of the EU energy and climate policy
}

\author{
Hansen, Anders Chr.
}

Publication date:

2008

\section{Document Version}

Publisher's PDF, also known as Version of record

Citation for published version (APA):

Hansen, A. C. (2008). The contributions of the hydrogen transition to the goals of the EU energy and climate policy. Paper presented at Workshop on socio-economic aspects of transitions to hydrogen \& fuel cell and other electric automotive transport in Europe, Roskilde, Denmark.

\section{General rights}

Copyright and moral rights for the publications made accessible in the public portal are retained by the authors and/or other copyright owners and it is a condition of accessing publications that users recognise and abide by the legal requirements associated with these rights.

- Users may download and print one copy of any publication from the public portal for the purpose of private study or research.

- You may not further distribute the material or use it for any profit-making activity or commercial gain.

- You may freely distribute the URL identifying the publication in the public portal.

\section{Take down policy}

If you believe that this document breaches copyright please contact rucforsk@kb.dk providing details, and we will remove access to the work immediately and investigate your claim. 


\title{
The contributions of the hydrogen transition to the goals of the EU energy and climate policy
}

\author{
Draft version by Anders Chr. Hansen, \\ Roskilde University, anders@ruc.dk
}

\section{Contents}

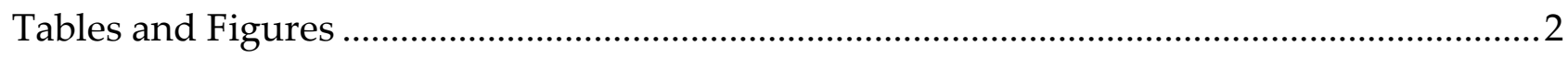

Societal priorities in energy and transport policy ………..........................................................

The integrated energy and climate policy ..............................................................................

Transitions to hydrogen fuels in transport..........................................................................

The beginning of the transition .........................................................................................

The fuel cell electric vehicle (FCEV) ............................................................................

The primary energy basis for hydrogen ...........................................................................

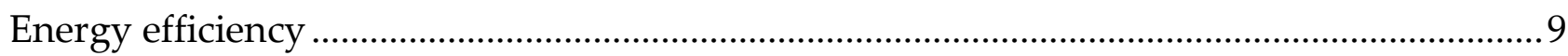

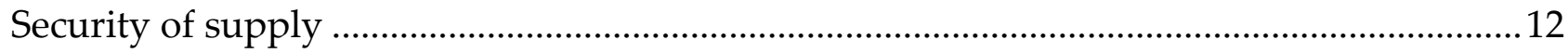

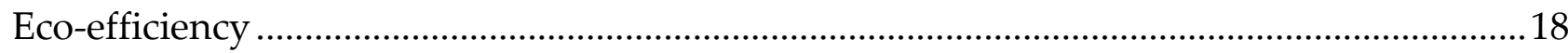

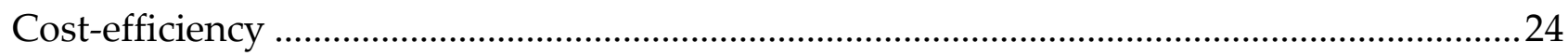

The prospective contributions hydrogen and fuel cell technology ........................................28

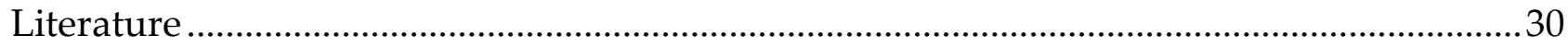




\section{Tables and Figures}

Table 1. Types of primary energy feedstock transformable to hydrogen..................................8

Table 2. Expected efficiency advantage of FCEVs above grid-independent HEVs with advanced ICE technology in 2010......................................................................................... 10

Table 3. Recent estimates of Europe's share of fossil fuel reserves..........................................12

Table 4. The EU share of the world recoverable uranium resources (RAR+inferred) by extraction cost.

Table 5. EU27 shares of OECD+BRICS renewable energy potentials realisable by 2020 . Percent.

Figure 2. Impact on European GHG emissions from passenger cars of replacing oil products by NATURAL GAS based hydrogen in fuel cell cars reaching a market share of $43 \%$ in 2050 .

Figure 3. Impact on European GHG emissions from passenger cars of replacing oil products by non-combustible based hydrogen in fuel cell cars reaching a market share of $43 \%$ in 2050 .

Figure 5. Impact on PM emissions from passenger cars of replacing oil products by CARBON FREE LEAN based hydrogen in fuel cell cars reaching a market share of $43 \%$ in 2050 in Europe.

Figure 6. Concentrations of PM 2.5 exceeding the health (mortality) limits in2000 and 2005.

Figure 7. Per km fuel cost of ICE and FCEV technology with natural gas based and nonfossil electricity based hydrogen. Best case. No taxes. 26

Figure 8. Per km fuel cost of ICE and FCEV technology with natural gas based and nonfossil electricity based hydrogen. Best case. Fuel taxes $€ 10 / G J$ on all fuels. 27 


\section{Societal priorities in energy and transport policy}

\section{The integrated energy and climate policy}

The most important goals of the integrated European energy and climate policy include security of supply, competitiveness and sustainability. Advances in energy efficiency have a positive effect on all of these goals and may therefore be seen as a goal in itself. The European countries have shared these goals for a long time, which is also reflected in the national energy policies and other common EU policies, such as the Environmental Action Programme, the internal electricity and gas markets, research and technology development programmes, etc.

The goals are specified by the Commission of the European Communities (2006) and in the decisions of the Council of the European Union (2007) at the landmark summit in March 2007: "increasing security of supply; ensuring the competitiveness of European economies and the availability of affordable energy; promoting environmental sustainability and combating climate change." (p. 11)

The European Union has initiated a large number of research, development, and demonstration projects focusing on specific technological and socioeconomic issues in the use of hydrogen and fuel cell technology in transport. These activities give rise to the more general question about the extent to which a transition to hydrogen from oil product transport fuels will contribute to achieving the goals of the European energy and climate policy. This is the question addressed in this paper.

\section{Transitions to hydrogen fuels in transport}

The mobility offered by automotive transport technologies is an important factor in enhancing the potentials for economic growth and at the same time an important aim of economic growth. Changing the energy basis of this mobility is maybe the most challenging component of the integrated energy and climate policy and it there.

The three goals of the energy and climate policy are only achievable to the extend alternatives to the historic reliance on fossil fuels are developed. Whereas, alternatives to fossil fuels - and fossil alternatives to oil - have been established for decades in the power

\footnotetext{
${ }^{1}$ The Commission of the European Communities (2007a) also mentions an additional goal, elimination of energy poverty (albeit in a slightly different meaning than known from the development world). This goal, however, will be excluded from the scope of this paper.
} 
and heat sector, and in industrial energy use, the transport sector is still almost entirely fuelled by oil products as it has been during almost a century. Thus, most of the innovation regarding fuels, vehicles and related infrastructures is "locked in" to the specific fuel-powertrain configuration of oil products and combustion engines. Businessas-Usual in the transport sector would seriously jeopardize all three goals (International Energy Agency (IEA) (2007)).

The technology lock-in links the growth of mobility with a parallel growth of demand for oil based fuels. The Energy Information Administration (EIA) US DOE (2008) forecasts a $50 \%$ increase in world demand of liquid transport fuels from 2005 to 2030. During the 2000s it has been optimistically assumed by the EIA, IEA and others that the price increases resulting from this gap would give rise to investments in oil production development. These investments and the new oil supplies they would have brought onstream have not materialised. Synthetic fuels based on tar sands, oil shale, or coal, and extraction of oil from more difficult and costly deposits may fill some of it, but these options are also in varying degrees characterized by a high energy consumption and environmental pressure in the production process.

On this background, there is an increasing recognition that we are at the beginning of a technology transition in transport energy from oil based fuels to alternative primary energy sources including other fossil fuels, biofuels, and non-combustible energy source based electricity.

A future transition to hydrogen is a challenging process that involves government coordination at all levels and consistently though a long period of maybe 50 years. For such a sustained all-European government policy to be realistic, the transition will have to contribute significantly to the overall policy goals listed above.

Using electricity as transport fuel makes use of the electro-motor technology, which in many respects is superior to the internal combustion engine. Combustion is necessarily associated with heat losses, emissions of air pollutants, and fairly complex engines, whereas electro-motors are free of these drawbacks. The problem is, that it electricity is difficult to use exactly for automotive engines because it is difficult to store. Hydrogen and fuel cell technology offers the possibility storing electricity as well as using hydrogen derived from combustible energy sources. ${ }^{2}$

\footnotetext{
${ }^{2}$ A full introduction to hydrogen and fuel cell technology is offered in Sorensen (2005).
} 
In this sense, hydrogen is like a convertible currency. It is possible to convert all kinds of energy to hydrogen and, then, convert it into any energy use. Thus, hydrogen can serve as a bridge between any other primary energy source than oil into use as a transport fuel. It is, however, important to note that hydrogen is only an energy carrier, not an energy source, as many people still seem to believe. Consequently, the contribution of using hydrogen as transport fuels must depend fully on how and from which primary energy sources, the hydrogen is produced. This is the starting point of the attempts to quantify these contributions below.

\section{The beginning of the transition}

\section{The fuel cell electric vehicle (FCEV)}

The fuel cell electric vehicle (FCEV) is an electric vehicle just as the battery electric vehicle (BEV), the hybrid electric vehicle (HEV) and the plug-in hybrid (PHEV). HEVs have been sold since 1997 and BEVs were marketed in a period in the 1990s and in the early 2000s, but with little success. Several large car producers have announced that they will reintroduce BEVs as well as PHEVs in 2009-10.

The drawback of the BEV is the low energy density of batteries resulting in a high weight and short range (100-200 km per charging, lower in cold climate) combined with long recharging and uncertain durability of batteries. There is a heated debate about whether innovation can change these properties significantly, but even BEVs with these properties can meet the requirements of a significant share of car users. In particular if the plans for building a network of battery exchange stations are realised (see http://www.betterplace.com).

The market segment that requires a longer range per refilling is already offered a range of advanced energy efficient ICVs and there is little doubt that they and their descendants will gain an increasing market share. Hydrogen also applies as fuel for a combustion engine (H2ICV) with few emissions. Car users who prefer electric driving, but with a range, performance, and refilling comparable to ICVs will be able to choose PHEV providing an extended range based on ICE technology. FCEVs will offer a fully zero emission solution, that is, a full electric mode with a range, performance, and refilling comparable to ICVs. FCEVs will definitely be more expensive than BEVs, when they are introduced in large numbers at the market, but they will address another market segment. There are still important innovative breakthroughs that must be achieved for the fuel cell technology to be a realistic option for mass production. The major challenge is the fuel cell 
itself, which today is made with heavy use of platinum as catalyst and with insufficient durability. Cheaper and more accessible catalysts and longer durability are necessary achievements before the technology can be used or "rolled out" in mass scale.

There is an agitated debate as to whether it will ever happen. On the one hand progress is undeniable taking place year by year, but when a technological breakthrough will take place and how it will look like is difficult to predict. There are very different views in the industry as to when and if such progress will be achieved, but widespread confidence in the innovative progress that will result of advancing the practical use of the technology. Front runners such as Chrysler and Honda will start production in modest series (Honda 200 vehicles over three years) already in the nearest years, but other car manufacturers plan to engage in FCEV production in 2020 or later.

The California state programme for advancing zero emission vehicles (ZEVs = BEVs and FCEVs) and partly zero emission vehicles (PZEVs = PHEVs, HEVs, H2ICVs a.o.) has been effective since 1990. It is probably the most ambitious program for advancing the use of these technologies. The zero emission programme demands from car makers at the California market that they supply at least 25,000 FCEVs or 7,500 BEVs and 58,333 H2ICVs (or similar) in 2012-14 to the Californian market (California Environmental Protection Agency Air Resources Board (CARB) (2008)).

The European Hydrogen \& Fuel Cell Technology Platform (HFP) (2007) has become a Joint Technology Initiative for Fuel Cells and Hydrogen, which is a public-private partnership for development and deployment of these technologies in Europe. The programme anticipate introduction of FCEVs on the European market in numbers of 400,000 to $1,800,000$ a year in the period 2015-2020. This will allow "mass roll out" in the 2020s. In Japan, the car industry similarly begins an early commercialisation phase in 2015 to prepare for assembly line mass production of FCEVs later (Fuel Cell Commercialization Conference of Japan (FCCJ) (2008)).

Such deadlines have been overrun before, but it without being too specific, we can assume that mass production and market availability of FCEVs will take place at least some time in the period 2020-25. This will mean that the FCEV can be produced at competitive costs, performance, and durability at some point of time in that period. This is the general assumption behind this paper.

It should also be noted that the hydrogen and fuel cell technologies are developed for other than automotive uses as well. Commercial opportunities for fuel cells are already 
identified and being exploited in niche markets such as forklifts, in emergency power generators back-up, in portable equipment such as laptops, and in stationary use as combined heat and power units. Synergies between innovative progresses in these different fields must be expected to advance the technology development for FCEVs. With the time frame assumed above, most of the contributions from the hydrogen transition to achieving the three goals will occur after 2020 and thus it is an important assumption that the policy continues after the 2020 targets have been reached.

\section{The primary energy basis for hydrogen}

At the current hydrogen market, hydrogen is a chemical rather than a fuel. Refineries use increasing amounts of hydrogen for desulphurisation and upgrading of heavier oil fractions. Ammonia production is another large hydrogen consumer. It is also used for numerous chemical processes involving a.o. metal, methanol, and plastics. Far most of the hydrogen is supplied by steam reforming of fossil fuels, in particular natural gas. A small fraction is supplied by electrolysis. It is produced by both technologies as a by-product as well as an on-purpose product.

An expanding market for hydrogen as a transport fuel will change the properties of the hydrogen demand from few large to many small consumers and from chemical industry intensive areas to car intensive areas. It will probably require a storage and transport network which differs from the current by a finer grid of pipelines and more delivery of compressed rather than of cryogenic ${ }^{3}$ hydrogen. Moreover, in the boundaries of expanding hydrogen delivery networks, on-site production of hydrogen can be expected to supply the transport hydrogen demand. That is, hydrogen production in small or medium scale natural gas based plants or electrolysers at fuel stations.

Future technologies for hydrogen production include among others high temperature electrolysis, gasification of biomass and hydrocarbons and separation of hydrogen from the gas, and microbiological processes. There are also high expectations to combustible fuel gasification with carbon capturing and sequestration (CCS) as a large source of the future hydrogen supply. The possible energy efficiency, emission leaks, infrastructures, and costs of this technology is, however, still too uncertain to determine its future competitiveness. Research and demonstration projects planned in the EU will probably make this knowledge available before 2020.

\footnotetext{
${ }^{3}$ Hydrogen made liquid by freezing to $-275{ }^{\circ} \mathrm{C}$.
} 
The performance and properties of these technologies are in the nature of the case unknown and it is even unknown whether they will be practical options in 2020 or later. When they are, they will have to be competitive with the important properties. Consequently, the role of the transition in achieving the societal goals will be considered mainly in the light of the two main hydrogen production technologies that are mastered today and the primary energy sources that can be expanded in the 2015-25 perspective. These pathways are shown in the following table.

Table 1. Types of primary energy feedstock transformable to hydrogen.

\begin{tabular}{|l|l|l|}
\hline & Renewable & Non-Renewable \\
\hline $\begin{array}{l}\text { Non-combustible } \\
\text { LT/HT electrolysis) }\end{array}$ & $\begin{array}{l}\text { Hydro, wind, wave, tidal, geo- } \\
\text { thermal, PV, microbial }\end{array}$ & Nuclear \\
\hline $\begin{array}{l}\text { Combustible } \\
\text { (gasification, steam } \\
\text { reforming) }\end{array}$ & Biomass & $\begin{array}{l}\text { Fossil: oil, gas, coal, tar } \\
\text { sands,.. }\end{array}$ \\
\hline
\end{tabular}

Table 1 shows that hydrogen can be produced directly from the combustible fuels by gasification, partial oxidation, or steam reforming or by electrolysis from non-combustible resources. The latter option is, of course, identical for batteries and the hydrogen and fuel cell solution is in many respects equal to a battery solution, albeit with higher energy density.

The question of how a future transition to hydrogen and battery stored energy for transport purposes will contribute to the European energy and environmental policy goals will be addressed below for each of these hydrogen pathways.

Currently, hydrogen is often produced in combination with other products. In oil refining hydrogen is a by-product as well as a main product used as an input to refining processes or for heating. Chlorine-alkali plants produce hydrogen as a by-product of electrolysis and ammonia production uses it as an input. The air industry produces hydrogen in combination with other gasses.

In the future, hydrogen will probably also be produced in combination with power, heat, other gasses and chemicals. Numerous other synergies can be expected to be exploited and it is difficult to foresee the resulting cost of hydrogen production. Production of hydrogen without by-products will most likely take place at hydrogen fillings stations and 
in other small and medium scale applications, but even in this field on-going innovation pursues synergies and by-products.

Thus, the following analysis is confined to assumptions of the key parameters that with certainty will be determining hydrogen fuel cost: conversion efficiencies and non-energy costs such as capital and labour costs of production plants and infrastructure. These simplifying assumptions reflect the general properties of a much more complex future transformation of primary fuel to hydrogen. In this way, the results should also attain more general validity than if they rest on very specific assumptions of distinct technologies. Fewer assumptions may also make the analysis more transparent.

\section{Energy efficiency}

The most attractive feature of the fuel cell technology is probably its superior energy efficiency as a part of a hydrogen-fuel cell-electro-motor powertrain, that is, in the Tankto-Wheel (TtW) part of the fuel chain. On the other hand, the energy loss in the Well-toTank (WtT) part of the fuel chain is considerable, but the total Well-to-Wheel (WtW) efficiency is potentially better than even HEV solutions.

Earlier studies of feasible scenarios for the introduction of hydrogen and fuel cell technology in automotive transport often compared the high efficiency of the fuel cell vehicle (FCEV) with rather fuel inefficient ICE vehicles. The Alternative Fuels Contact Group (2004) assumed the fuel cell system to be 100\% more efficient than an ICE system. The US National Academy of Science US National Academy of Science (2004) assumed a

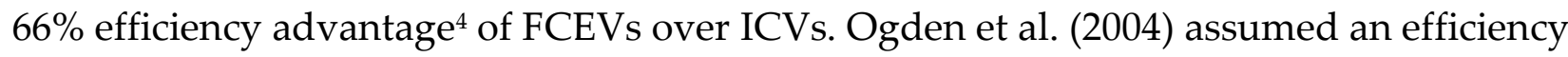
advantage of $79 \%$ and the International Energy Agency (2005) an efficiency advantage of $82 \%$ relative to advanced ICVs.

At the time when FCEVs are introduced to the market, however, they will most likely compete with vehicles that are far more energy efficient. The following table shows the efficiency advantages of FCEVs over future grid-independent HEVs expected by the European WtW database Edwards et al. (2007) and the GREET model in the US Argonne National Laboratory (2008). ${ }^{5}$

\footnotetext{
${ }^{4}$ An efficiency advantage of $66 \%$ equals an efficiency factor of 1.66, i.e. that an FCEV runs $66 \%$ further than an ICE on the equal energy content in the tank.

${ }^{5}$ These databases are the leading sources of comparable data for present and future technology choices of automotive technology.
} 
Table 2. Expected efficiency advantage of FCEVs above grid-independent HEVs with advanced ICE technology in 2010

\begin{tabular}{|l|c|c|}
\hline ICE technology $^{6}$ & WtW (2010+) & GREET (2015-20) \\
\hline $\begin{array}{l}\text { Port Injection Spark } \\
\text { Ignition (PISI) }\end{array}$ & $48-72 \%$ & $58-59 \%$ \\
\hline $\begin{array}{l}\text { Direct Injection } \\
\text { Compression Ignition } \\
\text { (DICI) }\end{array}$ & $50-55 \%$ & $45-47 \%$ \\
\hline
\end{tabular}

Source: Author's calculations based on Argonne National Laboratory (2008), Edwards, Griesemann et al. (2007).

The table shows that the expected fuel efficiencies of the nearest competing technologies are not that far from the expected fuel efficiency of the FCEV. In all cases the efficiency can be improved by taking more advantage of the battery-electro-motor system by using a plug-in battery. The efficiency of FCEVs is outstanding, but compared to its future competitors, one should not assume an efficiency advantage of more than $50 \%{ }^{7}$.

This assumption is used in the present paper as well as in the recent comprehensive study of feasible hydrogen roadmaps in Europe The HyWays Project (2008).

The flip side of the high energy efficiency of all grid-dependent electric vehicles (including BEVs and, HEVs and FCEVs) is the high energy loss in transformation of primary energy to power and hydrogen. Natural gas reforming and electrolysis are used today with conversion efficiencies of 60-65\% (see Hansen (2007b), (2007e)). For transport fuel use, it will additionally be necessary to use energy for compression, filling, a.o. today amounting to maybe $7-14 \%$ of the hydrogen produced.

It is difficult to predict system efficiency of hydrogen production from natural gas and electricity in 2015-2025. The European Hydrogen \& Fuel Cell Technology Platform (HFP) (2007) aims for a conversion efficiency by low temperature electrolysis of above $70 \%$ in 2015 and the US DOE (2007) for 71\% in 2017, but in system efficiency energy use for compression and refilling also has to be taken into account. For the conversion efficiency in natural gas reforming, the US target is 75\% in 2015 whereas there is no European target.

\footnotetext{
${ }^{6}$ PISI and DICI are basically petrol and diesel engines, respectively, but they can be adapted to various alternative fuels.

${ }^{7}$ A car that drives $35 \mathrm{~km} / 1$ has an efficiency advantage of $50 \%$ over a car that drives $23 \mathrm{~km} / \mathrm{l}$. Such levels of fuel efficiency could very well characterize the competition between FCEVs and other efficient vehicles in 2020.
} 
The innovative efforts for increasing efficiency includes adding waste heat to the process, using nano-manipulated catalysts, high pressure, and other improvements. Hansen (2007b), (2007e) finds it unrealistic for the system efficiency in 2020 to exceed $70 \%$ in daily use, whereas the worst case efficiency will be $62 \%$ for natural gas reforming for natural gas reforming as well as electrolysis.

It can be calculated that with a 50\% tank-to-wheel efficiency advantage and a system efficiency of conventional fuels of $92 \%$, the system efficiency can be as low as $62 \%$ before the overall well-to-wheel efficiency is lower for hydrogen and fuel cell technology than for the conventional oil product and ICE technology (Hansen $(2007 \mathrm{c})$ ). Thus, with these assumptions a minimum system efficiency of $62 \%$ is required for the hydrogen and fuel cell technology to contribute to a general progress in energy efficiency.

Still, it is a challenge to reach even the worst case scenario for hydrogen production efficiency. For instance, hydrogen losses of 5-10\% was reported by the European hydrogen bus project (The CUTE Project (2008)) due to purging of system components and background leakage. With such a loss rate it can be difficult to achieve a satisfactory system efficiency, but it is caused by technical problems that can be solved.

When hydrogen becomes a fuel rather than a chemical, it will also be a problem to expand the practice of using cryogenic hydrogen delivery and storage and at the same time maintain high system efficiency because of the large energy loss associated with this method.

It is a major concern for the prospects of fossil fuel based hydrogen with CCS whether the associated energy loss due to the CCS can be curbed sufficiently for the overall WtW efficiency of the hydrogen fuel to match that of oil products and of non-fossil based hydrogen.

The lower limit of $62 \%$ system efficiency as a societal priority should, however, not be interpreted as an absolute limit. First, the increasing demand for hydrogen in the refining processes leads to lower system efficiency for conventional fuels. Second, the different energy forms involved (oil, gas, coal, electricity, heat, etc.) differ in usefulness and thus in value. One GJ of an energy commodity does not necessarily equal one GJ of the other. They also differ by environmental as well as security of supply properties. Third, conversion efficiencies can probably be developed significantly by learning-by-doing. Irrespective of hydrogen pathway, it is possible to perform with a higher WtW efficiency because of the fuel cell and electro-motor power-train. Thus, even if replacing one GJ petrol or diesel by one GJ hydrogen will add 50\% to the transport service delivered, the 
production of one GJ hydrogen requires more energy than the production of one GJ petrol or diesel. In a $\mathrm{WtW}$ perspective, the gain in transport services can be reduced to $0-14 \%$ if the system efficiency is $62-70 \%$ (respectively). Thus, minimum efficiency standards and economic incentives such as those used elsewhere to ensure energy efficiency may be necessary to ensure a significant contribution from the hydrogen transition to the overall efficiency of transport and economic activities in general.

\section{Security of supply}

Security of energy supply to the European Union is a complex problem that involves at long list of problems of which we will concentrate on four: First, the geological-economic capability of supply to respond to the increasing global demand for energy at the world markets. Second, the geographical distribution of the potential supply responses (i.e. reserves and resources), entailing geopolitical and market power issues. Third, the resilience of the global production, transport, and transformation networks providing the technical basis for the throughput of combustible energy. Fourth, the vulnerability of the European economies to increasing relative scarcity of primary energy commodities reflected in their world market prices.

Hydrogen produced with or without CCS from natural gas or coal is in many scenarios expected to supply a large share of the market for hydrogen transport fuel in the future. Such a transition path will diversify the primary energy basis of transport from oil to natural gas and coal and in this sense improve the security of supply. Natural gas and coal supplies are, however, troubled by similar constraints due to geological-economic scarcity, geographical distribution of reserves, resilience of the global throughput, and vulnerability of the economies to supply failure and world market price increases.

Table 3. Recent estimates of Europe's share of fossil fuel reserves.

\begin{tabular}{|l|l|l|l|}
\hline \multirow{5}{*}{ Oil } & BP Statistical Review & Year-End 2007 & $1.3 \%$ \\
\cline { 2 - 4 } & Oil \& Gas Journal & January 1, 2008 & $1.1 \%$ \\
\cline { 2 - 4 } & World Oil & Year-End 2006 & $1.3 \%$ \\
\hline Natural Gas & BP Statistical Review & Year-End 2007 & $3.3 \%$ \\
\cline { 2 - 4 } & CEDIGAZ & January 1, 2008 & $3.5 \%$ \\
\cline { 2 - 4 } & Oil \& Gas Journal & January 1, 2008 & $2.8 \%$ \\
\cline { 2 - 4 } & World Oil & Year-End 2006 & $2.7 \%$ \\
\hline
\end{tabular}




\begin{tabular}{|l|l|l|l|}
\hline Coal & $\begin{array}{l}\text { Recoverable } \\
\text { Anthracite and } \\
\text { Bituminous }\end{array}$ & $2.0 \%$ \\
\cline { 2 - 4 } & $\begin{array}{l}\text { Recoverable Lignite } \\
\text { and Subbituminous }\end{array}$ & & $9.1 \%$ \\
\cline { 2 - 4 } & $\begin{array}{l}\text { Total Recoverable } \\
\text { Coal }\end{array}$ & $5.5 \%$ \\
\hline
\end{tabular}

Source: Energy Information Administration (EIA) US DOE (2008), statistical appendices.

Table 3 shows that Europe is not endowed with indigenous fossil energy sources. Only lignite and subbituminous coal is apparently abundant compared to the $9 \%$ of the world population living in Europe.

Natural gas is expected to supply an increasing share of European energy demand in the future, but it is a non-renewable resource and the supply cannot increase forever. Much of the remaining reserves are comfortably situated around Europe in Russia, Central Asia, the Middle East, and North Africa, but as Stern (2007) points out, Europe will not be the only market for natural gas from these sources in the future. The important Russian and Central Asian reserves that Europe counts on will not least be in demand from the Russian market itself, not to mention the rest of Asia. Stern (2007) also questions whether the institutional frameworks in the natural gas producing countries will be adequate for the investments needed to bring all the natural gas on-stream. Thus, we should not take for granted that the European import from these sources can increase beyond 2020. This would severely limit the role that natural gas can play as a transitory energy source for transport.

The ongoing expansion of the capacity for liquefaction in the gas producing countries and for regasification in Europe will certainly improve the resilience of the throughput of natural gas from sources to Europe, but it cannot change the increasing geologicaleconomic scarcity.

Three quarters of the remaining global oil reserves are controlled by only nine countries, but the same countries control a similar share of the remaining natural gas reserves that are relevant to Europe (Hansen (2007d)).

The market price of natural gas imports to Europe has always been closely linked to the world market price of oil (see Hansen (2007d), (2007e)). Ongoing attempts to create an independent spot market price for natural gas have achieved short term deviations in the 
spot market price, whereas the long term relation between the oil price and the natural gas spot market price seem to persist (see European Commission - DG COMP (2004), Panagiotidis and Rutledge (2007) and for the US Villar and Joutz (2006)). Fundamental market mechanisms will most likely strengthen the close covariance of natural gas and oil prices as natural gas increasingly serves as primary energy basis for transport energy, directly or via hydrogen.

The European economy is vulnerable to increasing oil and gas prices because of its significant net-imports of oil and gas compared to the GDP. On the member state level, this vulnerability is considerably larger in the new member states than in the old member states (Hansen (2007d)). Thus, an oil price increase implies a significant leak of national income from the economic circuit in Europe. Replacing oil and natural gas imports by energy from European sources would not only improve the overall terms of trade between Europe and the rest of the world, but also create jobs in the industries, providing the indigenous energy supply. Replacing oil by natural gas or even by coal imports, however, does not have the same effects. Only to the extend that the Well-to-Wheel efficiency of energy use is better because of the hydrogen and fuel cell technology associated with the natural gas and coal imports. This can, however, only amount to marginal improvements. Coal is, according to the government reports on remaining reserves, a relatively abundant energy resource with plenty of proven and recoverable reserves, but the quality of these data is increasingly questioned by independent centres for resource assessment. The Energy Watch Group (2007) even predicts that the global coal production due to geological-economic scarcity will reach its peak in the 2020s. According to Gerling et al. (2006) only $6 \%$ of the global hard coal reserves and $3 \%$ of the brown coal reserves are situated in Europe (classifying coal differently than in Table 3). It is ,however, questionable whether these reserves should be classified as economically recoverable reserves in the same way as, .e.g., South African coal is. In Europe the inexpensively exploitable coal reserves were mined long time ago, and the coal production has been in decline for decades as it becomes still more expensive to mine coal from still deeper and thinner seams. Much of the European hard coal production is only kept alive with the help of considerable government subsidies. These are allowed by the EU despite the fact that they obviously work against the Lisbon goal of economic growth as well as the climate policy goal of reducing $\mathrm{CO}_{2}$-emissions. The only reason for allowing it, after all, is to maintain access to indigenous sources of energy (The Council of the European Union (2002)). When subsidies and the restructuring of European coal industry is terminated, the reserves will likely be considerably lower. 
Thus, much of the coal consumed in Europe originates from distant sources such as South Africa, Colombia, and Russia. A value added chain analysis by Gerling, Rempel et al. (2006) showed that about half the cost of hard $\mathrm{coal}^{8}$ in Europe in 2005 was transport costs that vary closely with the price of oil. In addition, there is a substitution effect on the coal cost net of transport costs. It is not as strong as the oil-gas substitution effect, but it will be rising if more coal is used for production of synthetic diesel or DME9. Thus, switching from oil to coal as a primary energy basis for transport fuels will only partly escape the negative effects from the oil market.

The ongoing innovation of CCS technology will probably before 2020 show which solutions we can expect to be competitive. In many future scenarios, this technology is expected to open up for large amounts of low carbon energy to the European market. A note of caution is, however, warranted on this perspective keeping the high transport cost of coal in mind. When a competitive CCS technology is ready, it will be available all over the world. Thus, it is possible, that it will be more competitive to generate hydrogen from coal at the location of coal extraction (e.g., South Africa, Central Asia) and then ship the hydrogen to Europe, than it will be to ship the coal and generate the hydrogen in Europe. In that case, CCS technology in Europe would, however, still be useful in combustion and gasification of European combustible energy sources.

Table 4. The EU share of the world recoverable uranium resources (RAR+inferred) by extraction cost.

\begin{tabular}{|l|l|l|l|}
\hline & $<$ USD 40/kgU & $<$ USD 80/kgU & $<$ USD 130/kgU \\
\hline EU share & $3.4 \%$ & $0.5 \%$ & $1.9 \%$ \\
\hline
\end{tabular}

Source: OECD Nuclear Energy Agency and the International Atomic Energy Agency (IAEA) (2008).

Uranium deposits occur in many countries, but as shown in Table 4 the economically recoverable reserves are primarily located outside of Europe like oil and gas reserves. The

\footnotetext{
8 The energy density of lignite is to low to warrant long transport.

${ }_{9}^{9}$ Rising coal demand along with a rising oil demand from China and India also leads to simultaneously rising oil and coal prices at the world market. Rising coal prices at the world market may, on the other hand, make more European coal resources economically recoverable.
} 
OECD Nuclear Energy Agency and the International Atomic Energy Agency (IAEA) (2008) expects that it is possible to double the global uranium extraction at cost below USD $80 / \mathrm{kgU}$ to approximately $120,000 \mathrm{tU}$ per year in 2016. At a constant rate of extraction these resources would allow for uranium extraction well into the 2040s.

The binding constraint for expansion of nuclear energy in Europe is, however, rather public acceptance than this economic-geological scarcity. Locations where the general public accepts nuclear energy production, fuel processing, and waste deposition are very scarce and has been so for decades, irrespective of economic costs. New generations of nuclear energy technology may change that as well as make use of more abundant resources such as thorium.

The Commission of the European Communities (2007b) considers generally renewable energy to "contribute to security of supply by increasing the share of domestically produced energy, diversifying the fuel mix, diversifying the sources of energy imports and increasing the proportion of energy obtained from politically stable regions." (p. 14). They are, however, also subject to a combined geographical-geological-economic scarcity as many of them are land intensive. This is a matter of land use (less severe for offshore wind power) where several other interests are at play. Thus, the resources that realistically can be recovered depend to a high degree on public acceptance which in turn is affected by the arrangements for redistribution of the resource rents. Moreover, many renewable resource technologies are under development and their development depends partly on the rate of their deployment. Due to these complicated aspects, it is difficult to assess the economically recoverable renewable energy resources.

For renewable energy, resource assessments consequently differentiate between the physical (or theoretical), practical (or technical) and realisable (or economic) potential within a given time frame. According to a recent study of the renewable energy potentials in the OECD countries and the BRICS (Brazil, Russia, India, China and South Africa), the the total renewable energy potential amounts to approximately 9,000 TWh electricity, 5,700 TWh heat, and 1,700 TWh biofuels for transport in the 2020 perspective for these countries. The European shares of these potentials are shown in Table 5.

Table 5. EU27 shares of OECD+BRICS renewable energy potentials realisable by 2020. Percent.

\begin{tabular}{|l|l|}
\hline Biogas & $19 \%$ \\
\hline Solid biomass & $20 \%$ \\
\hline
\end{tabular}




\begin{tabular}{|l|l|}
\hline Renewable municipal waste & $15 \%$ \\
\hline Geothermal electricity & $11 \%$ \\
\hline Hydropower & $11 \%$ \\
\hline Solar photovoltaics & $23 \%$ \\
\hline Solar thermal electricity & $33 \%$ \\
\hline Tidal and wave energy & $80 \%$ \\
\hline Onshore wind & $31 \%$ \\
\hline Offshore wind & $59 \%$ \\
\hline Total RES-E & $20 \%$ \\
\hline Biofuels (domestic) & $27 \%$ \\
\hline Solar thermal heat & $27 \%$ \\
\hline Geothermal heat & $25 \%$ \\
\hline Biomass CHP heat & $24 \%$ \\
\hline Total RES-H & $25 \%$ \\
\hline Source: Organisation for Economic Cooperation & $97 d$ D \\
\hline
\end{tabular}

Source: Organisation for Economic Cooperation and Development (OECD) (2008).

The EU is inhabited by $15 \%$ of the total OECD and BRICS population and in this perspective EU is especially well endowed with wind, wave/tide, and solar thermal electricity resources. Such renewable and non-combustable energy resources could form an indigenous primary energy basis for hydrogen.

Like coal, indigenous first generation biofuels from Europe are not competitive with the products of large foreign producers. For second generation technologies, the biomass resources shown in Table 5 can be rich sources of either "classical" biofuels or hydrogen production.

Especially, the European wind resources are relatively abundant, in particular, in Northern Europe and in mountain areas. The enormous offshore wind resources in the Atlantic, the North Sea, and the Baltic Sea are only little exploited. Concerted investments in the necessary transmission lines and adapting the national power grids to allow more renewable energy production are central EU decisions for harvesting these resources.

The non-combustible energy resources are of particular interest since most of them provide the same power load around the clock. This was formerly regarded as a 
drawback, but with the possibility of storing electricity in car batteries and hydrogen, the drawback can be reversed to an advantage. If Europe's rich endowment of noncombustible resources is exploited, the result will be a significant supply of low cost offpeak electricity providing a stable and steadily increasing primary energy source of hydrogen. It will also reduce the vulnerability of the European economies to increasing oil prices and create job it will reduce the worries - justified or not - of hold-up of the throughput from the countries exporting oil and gas to Europe.

Indigenous primary energy is an important aspect of security of supply and hydrogen can be the link between transport and the considerable wind, wave/tide, and geothermal electricity resources that Europe command. In particular, in the period up to 2020, it must be expected that wind power will expand considerably in Europe, producing large amounts of off-peak energy with little other competition than storage for transport use.

\section{Eco-efficiency}

The EU target of reducing $\mathrm{CO}_{2}$ emissions by $20 \%$ of the 1990 level in 2020 also implies a similar targeted rate of progress in eco-efficiency, the ratio of an indicator of economic activity to an indicator of the environmental pressure, it causes. On the level of aggregate GDP for EU27, the macroeconomic requirement derived from the GHG target is to sustain an average growth rate in eco-efficiency of 3.3\% from 2005 to 2020 . This is ambitious too as the GHG-efficiency growth rate achieved from 1995 to 2005 was on average $2.4 \%$.

Since the start of the GHG accounts in 1990, transport activities have caused a rising share of Europe's total GHG emissions to the level of 21\% in 2004 (EU15). The $20 \%$ target is hardly achievable without reversing this trend and it raises the question whether hydrogen and fuel cells in automotive use can contribute to this.

The immediate answer is no for the simple reason that until 2020 there will in any case be a very small number of fuel cell vehicles on the roads. Most likely, they will be too few to make any difference in the European GHG accounts. However, climate policy doesn't end in 2020 and the perspective as far as the EU is concerned is to continue to reduce GHG emissions to a level that is 60-80\% lower than the 1990 level in 2050.

To study the possible contribution to GHG emission reduction from the introduction of passenger cars with hydrogen and fuel cell technology on the European market, a series of scenarios were produced with the Sustainable Mobility Project Model (World Business Council for Sustainable Development (WBCSD) and International Energy Agency (IEA) (2004)). They are documented in Hansen (2007a). 
The scenarios introduced passenger cars with fuel cell technology on the European market from 2015 with a market share growing to $43 \%$ in 2050. Two different scenarios with respect to feedstock for hydrogen production were created. One scenario assumed that the hydrogen was produced on the basis of natural gas whereas the other scenario assumed that it was produced by electrolysis from renewable or nuclear energy.

The contribution to the GHG emission reduction was very different in the two scenarios. In the natural gas based scenario, the aggregate GHG emissions from passenger cars in Europe 2050 was reduced by $14 \%$ corresponding to $5 \%$ of the emissions from the total transport sector. This scenario is shown in the figure below.

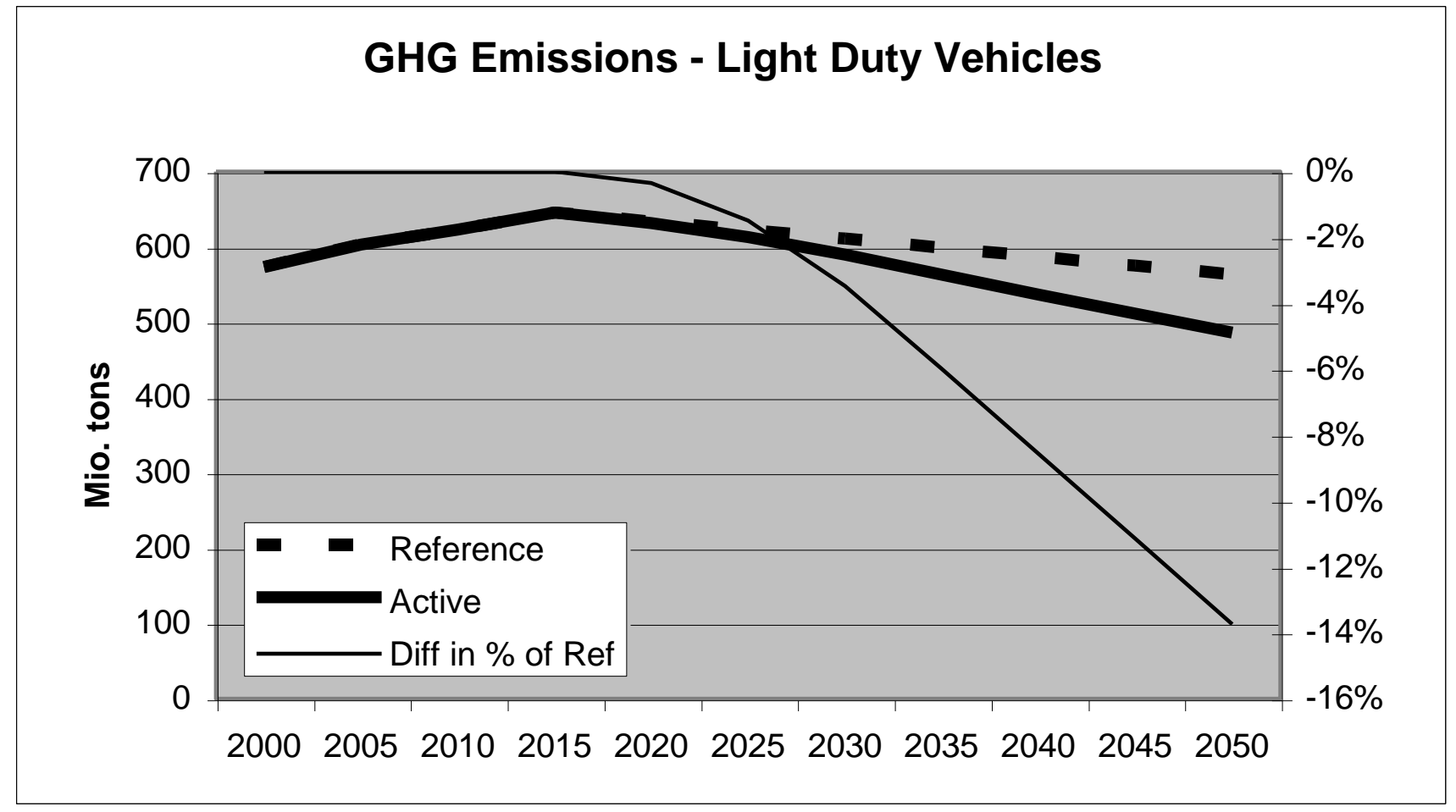

Figure 1. Impact on European GHG emissions from passenger cars of replacing oil products by NATURAL GAS based hydrogen in fuel cell cars reaching a market share of $43 \%$ in 2050.

Source: Hansen (2007a).

The reference scenario emissions in Figure 1 (the dotted bold curve, left axis) are expected to decline due to a higher market share of energy efficient cars (particularly diesel) as fuel prices increase. The active scenario shows the emissions that would result from introducing hydrogen and fuel cell cars (bold curve, left axis). The slim curve refers to the right axis and shows the deviation of the active from the reference scenario in percent. 
The result shows that there will be a reduction in GHG emissions, but a rather modest one. Even if all diesel and petrol cars were replaced by fuel cell cars, half of the GHG emissions would still remain because hydrogen is produced by natural gas. This is, however, not necessary. The same scenario with hydrogen produced from non-combustible sources can produce quite different results.

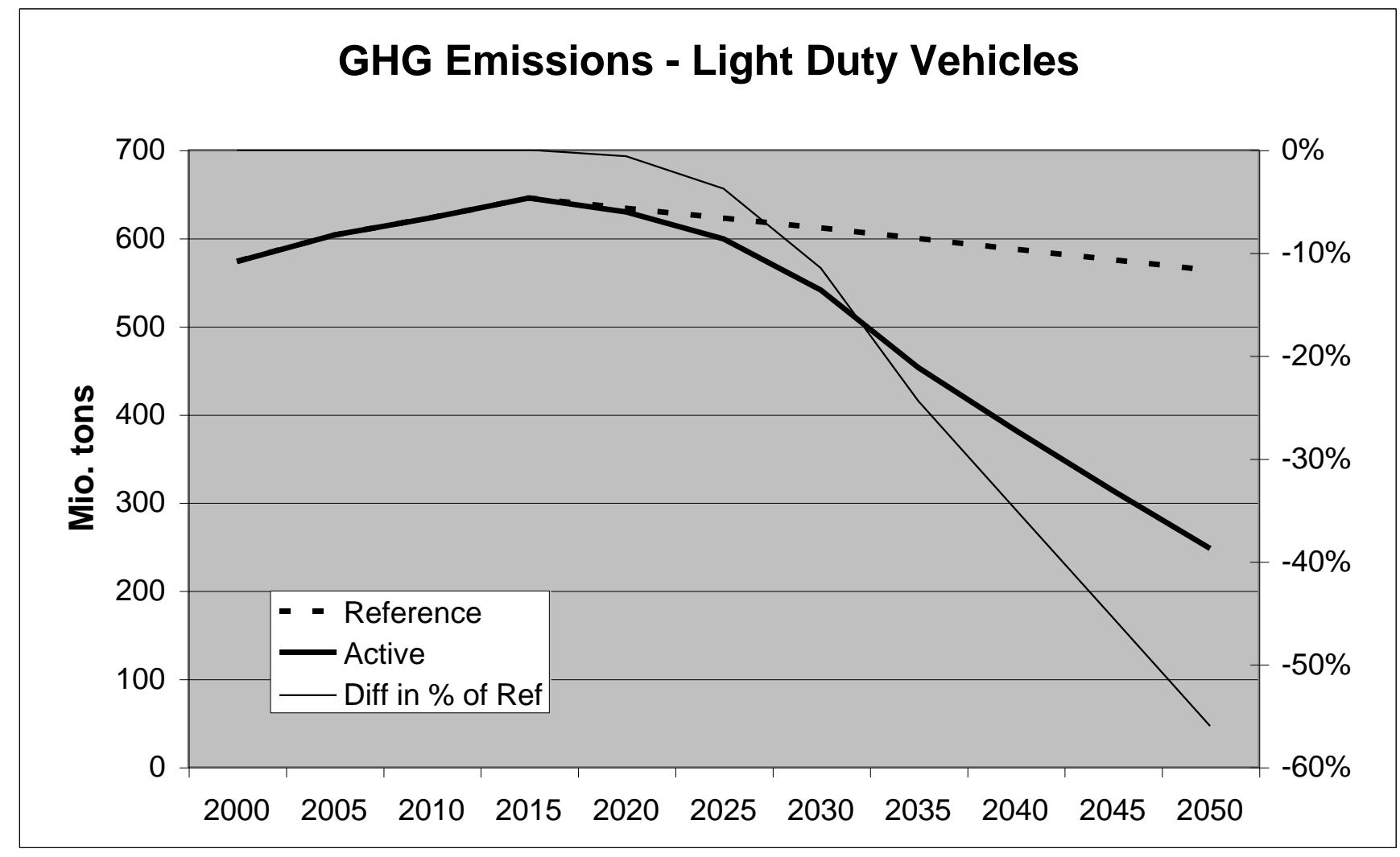

Figure 2. Impact on European GHG emissions from passenger cars of replacing oil products by non-combustible based hydrogen in fuel cell cars reaching a market share of $43 \%$ in 2050.

Source:Hansen (2007a).

Figure 2 shows that with the production of hydrogen from $\mathrm{CO}_{2}$ neutral feedstock the emissions from passenger car transport will be reduced by almost $60 \%$.

With reference to these scenarios, European governments would have important environmental reasons to support hydrogen as a transport fuel as long as it is based on non-combustible energy, but only little reason if it is based on natural gas or coal without carbon capturing and sequestration. 
Biomass and coal based hydrogen with CCS can provide hydrogen fuel with GHG emissions close to the non-combustible alternative depending on the actual provision of the fuel, the hydrogen production technique and the use of CCS.

The two scenarios were also used to study the impact on local air pollutants emitted from passenger car transport such as particle matter (PM), nitrate oxides (NOx), volatile organic compounds (VOC), and carbon monoxide (CO). These pollutants affect human mortality and morbidity and are responsible for damages on environmental qualities.

The study showed that on the aggregate level the emissions of these pollutants were already drastically reduced in the reference scenario at the time when the fuel cell cars are introduced to the market. This is a result of the EU and member state efficiency requirements, fuel and exhaust standards, and other initiatives under the CAFÉ programme for eliminating air pollution that damages human health. The results are shown below.

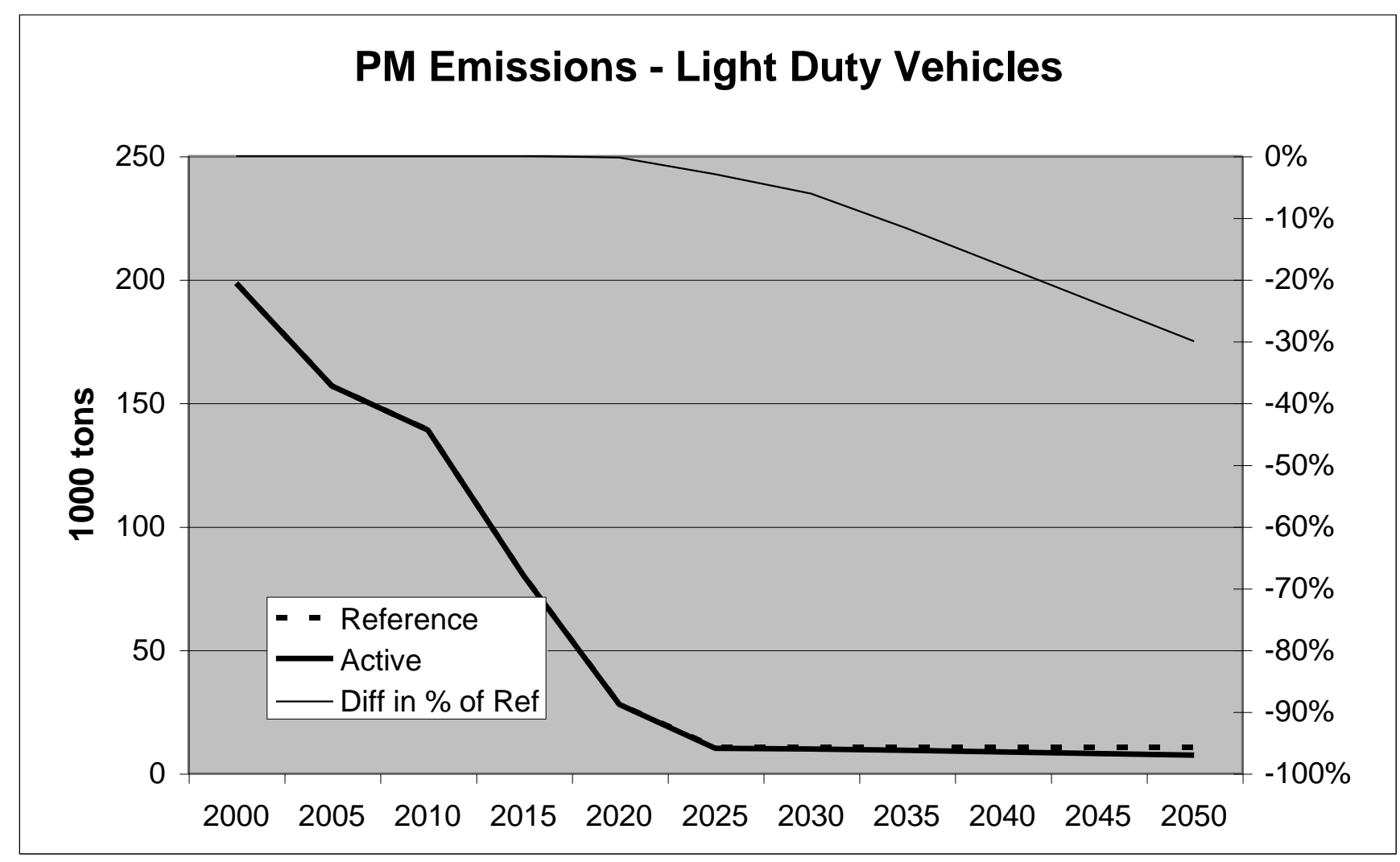

Figure 3. Impact on PM emissions from passenger cars of replacing oil products by CARBON FREE LEAN based hydrogen in fuel cell cars reaching a market share of $43 \%$ in 2050 in Europe. 
Source: Hansen (2007a).

The non-combustible based hydrogen in Figure 3 shows a very modest impact of using green carbon free hydrogen for transport. This is because the CAFE-policies aim at eliminating the health damaging pollution from stationary as well as mobile sources. The reference scenario assumes that these programmes will be implemented affectively and timely and with the desired results. These assumptions may be overly optimistic, but much of the local air pollution can be avoided by applying the exhaust, engine, and fuel standards, filters, etc. as planned according to the the EU CAFÉ policies.

Natural gas reforming would relocate emissions from the mobile to the stationary sources and with the same assumptions of effective elimination of local pollutants a similar result could have been achieved.

The aggregate emissions shown in Figure 3 are, however, not the adequate indicators for local pollutants. These pollutants are trapped in locked air-sheds and city air at several locations around in Europe. In these locations governments have a particular reason for continuously supporting the use of electric vehicles whether battery or fuel cell electric and even in some places hybrid electric. The following figure shows how these spots on the European looked in the year 2000 and how they are expected to look in 2020 after the implementation of the EU Air Strategy and Maximum Climate Action policies. 


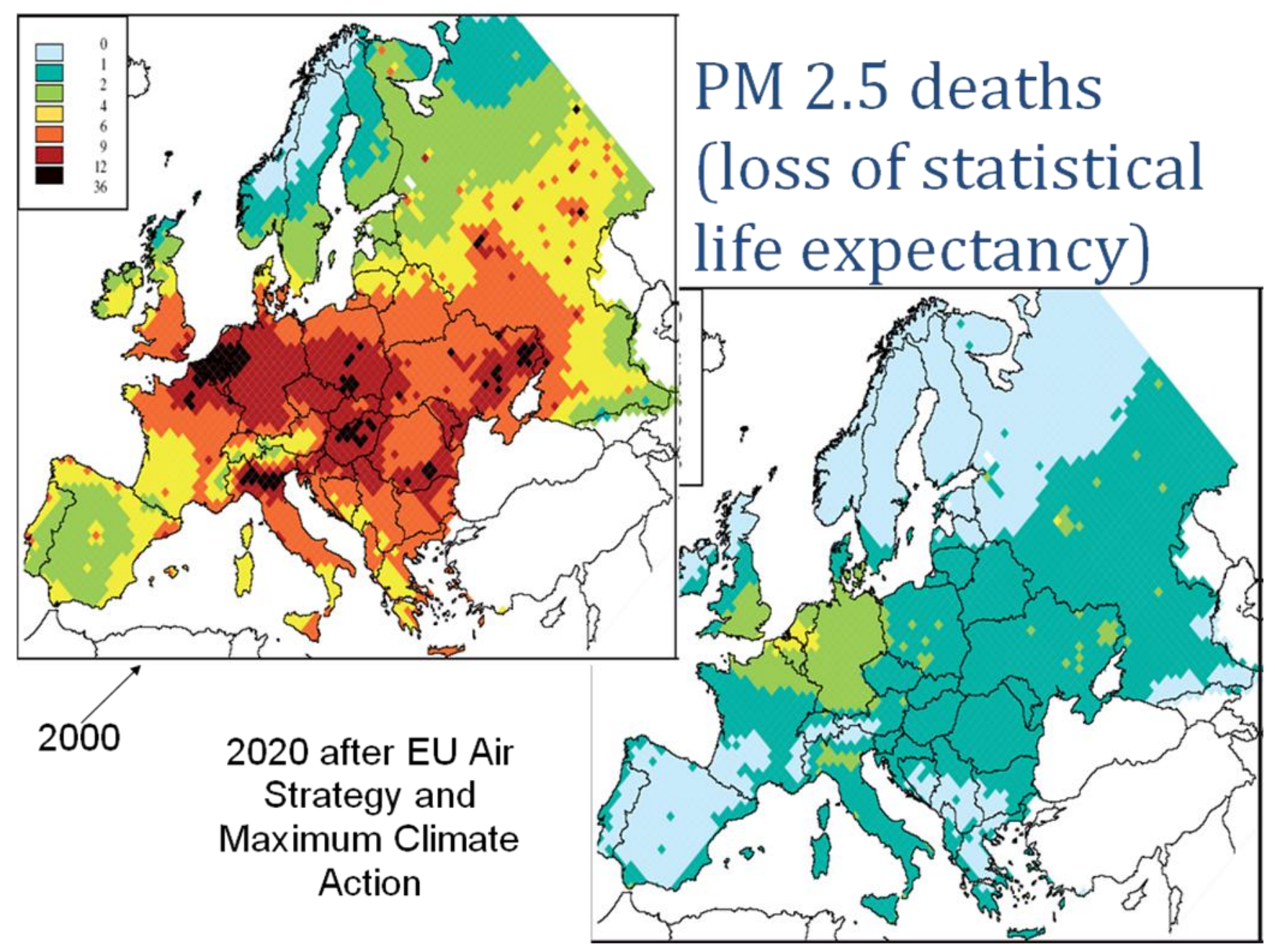

Figure 4. Concentrations of PM 2.5 exceeding the health (mortality) limits in 2000 and 2005.

\section{Source: Hansen (2007a).}

The indicator used in the figure is the particle caused mortality measured as the loss of statistical life expectancy due to very fine particles (2.5 microns) from combustion. Several other local pollutants could have been mapped here, but their geographical distribution and intensity are not very different from that of the fine particle pollution shown here.

The maps show in accordance with the modelled scenarios above that the programmes improving the fuel and exhaust standards, emission standards etc. in Europe have the potential of solving a large part of the most severe pollution problems, but not all. There is a strong case for regional policies on parking fees, parking rights, road tolls, etc. favouring the use of BEVs, HEVs, PHEVs, and FCEVs. Policies along these lines are already being planned or adopted in cities like London and Milano. 
Summing up, the high fuel efficiency of FCEVs contributes in any case to reduction of GHG emissions as they gain a higher market share at the cost of ICVs or HEVs. This contribution is, however, very small. In the scenarios above, when basing hydrogen on non-combustible energy sources or fossil sources with CCS, even a 43\% market share in 2050 would eliminate more than half of the GHG emissions from passenger cars in 2050.

The effect on emissions of local pollutants is a different story. The regulation of emissions of local pollutants not only from car exhaust, but also from stationary sources is capable of reducing the future pollution considerably, even before the hydrogen and fuel cell technology is matured to introduction in large scale in automotive transport. Thus, the hydrogen and fuel cell technology is not essential for reducing the bulk of the air pollution causing health damages. However, the results shown in Figure 4 indicate that electric vehicles - and not least FCEVs - with their zero tail pipe emissions will be essential for eliminating the rest of the unacceptable health impact from air pollution. This conclusion applies in particular to the European regions with the highest population (and car) density where fuel cell busses also can be expected to be an important part of the solution.

\section{Cost-efficiency}

The cost efficiency of FCEVs relative to their competitors depends on the vehicle ownership costs as well as the fuel cost per kilometre. The cost of an FCEV put into mass production in 2020 cannot be predicted with any degree of useful accuracy. In broad terms, the future use of the technology rests on assumptions that costs can be reduced by an order of magnitude through research in design, materials, etc., and, when produced in large scale series, by another order of magnitude through industrial learning. In that perspective, any calculation of a more exact level of production costs for future FCEVs will be very speculative. Here, it is just assumed that it will be possible at some time in the 2015-2025 period to produce an FCEVs that are comparable with advanced HEVs, PHEVs, and advanced ICEs in cost, performance, and durability. The focus can then be concentrated on the fuel cost per kilometre. The fuel cost is highly dependant of the international oil price, which is also difficult to predict for the period of 2015-2025 with any degree of certainty. However, we can calculate the threshold value of the oil price that makes hydrogen competitive as a transport fuel.

Hansen (2007b) uses this approach and calculates similarly the fuel costs without very specific assumptions about the specific technologies that will deliver the hydrogen. The model is based on the simple assumptions of the cost of the primary energy commodity, the conversions factors and the non-energy costs of each link in the fuel chain. 
The transport fuel pathways considered are oil to petrol and diesel, natural gas to hydrogen, and non-combustible energy to hydrogen. Coal is not considered, because the CCS technology and infrastructure will hardly be developed to a competitive technology before the 2020s. Biomass-to-hydrogen pathways are also not considered for similar reasons.

The natural gas price follows the oil price quite closely although not as closely as the petrol and diesel prices. Non-combustible energy are expected to deliver electricity at a long run marginal cost basis $€$ c5.0-7.3 per kWh ( $€$ in 2005 prices). The actual level of electricity prices in the day time may be considerably higher since it depends on the marginal costs of power production, which is typically based on natural gas and oil. Thus, to take advantage of the European non-combustible energy resources for hydrogen will be a challenge to the design of the complex European systems of $\mathrm{CO} 2$ quotas, subsidies, taxes, green certificates, and feed-in tariffs.

The statistical covariation between the spot market price for oil and the retail price of fuels is taken to reflect the system efficiency (conversion, transport, storage, retail) and nonenergy costs of the fuel chain. The same approach is used for natural gas. For hydrogen, the fuel chain doesn't exist yet and the approach here is to use the retail natural gas price and electricity price with expected system efficiency ratios and non-energy costs of the future hydrogen fuel chain.

For natural gas based hydrogen the system efficiency is assumed to be 70\% and the nonenergy costs to be $€ 10$ per GJ in the best case. In the worst case a system efficiency of $62 \%$ and non-energy costs of $€ 14$ is assumed. For electrolysis, the best/worst case assumptions are accordingly $70 \% / 65 \%$ and $€ 10 / € 15$ per GJ. The reader is referred to Hansen (2007b) and Hansen (2007e) for additional background information about these assumptions.

Based on these assumptions, the threshold prices can be identified as the intersections of the cost per km curves in Figure 5 below. 


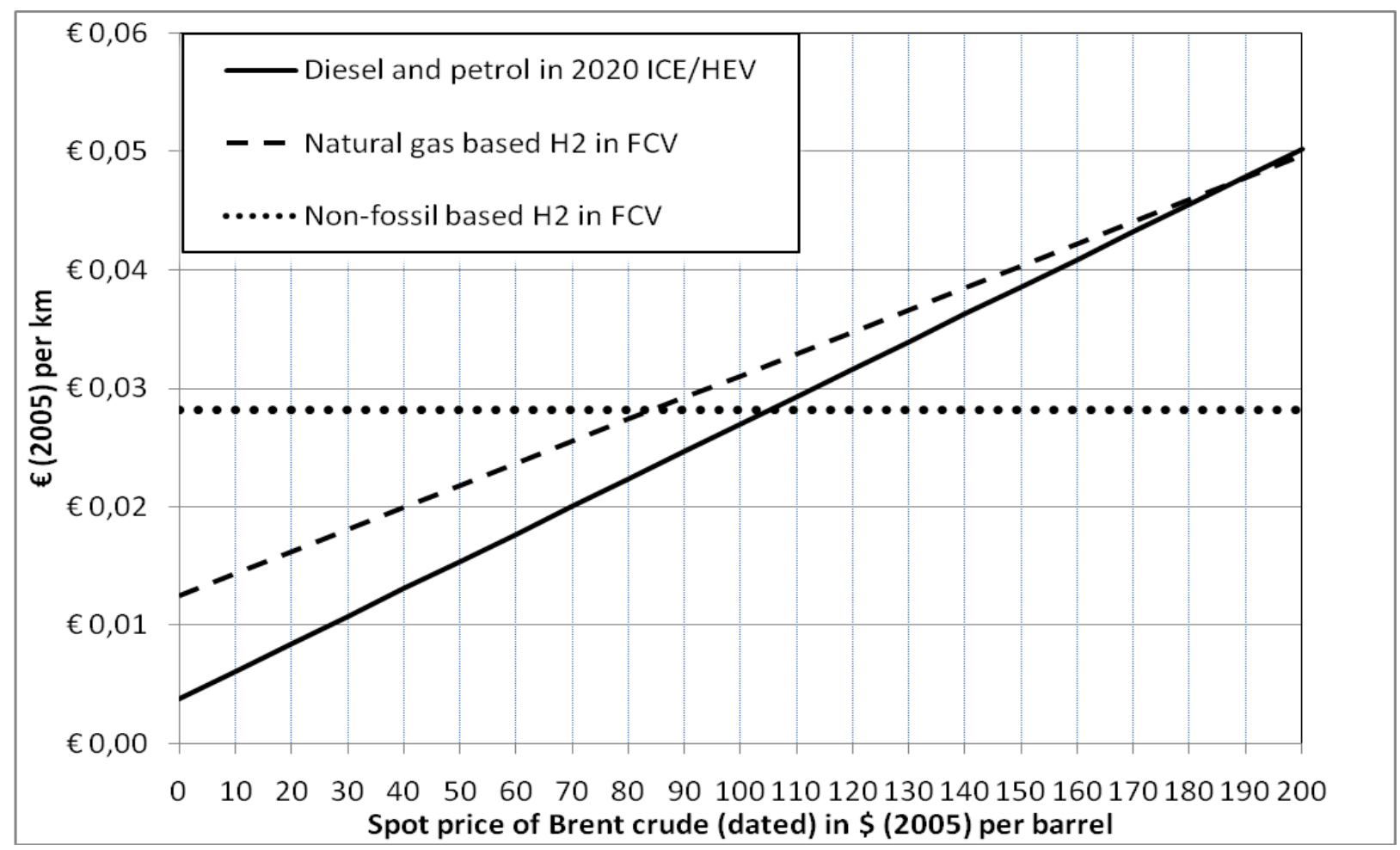

Figure 5. Per km fuel cost of ICE and FCEV technology with natural gas based and nonfossil electricity based hydrogen. Best case. No taxes.

The intersections show threshold oil prices of $\$ 190$ per barrel (Brent quality, in 2005 US dollars) for natural gas based hydrogen vs. conventional fuels in the best cases (in the worst case, it is far outside the scope of the diagram). However, the study also shows that at this level of oil price, hydrogen based on non-combustible energy has already been competitive to conventional fuels since the oil price was $\$ 105$ and to natural gas based hydrogen at an oil price of $\$ 85$ (in the worst case $\$ 175$ and $\$ 135$ ). Only if prices are lower than $\$ 85$ per barrel (\$135 in the worst case) will natural gas based hydrogen be competitive to non-combustible based hydrogen (but not to conventional fuels).

Most of the earlier studies such as The Alternative Fuels Contact Group (2004), The US National Academy of Science US National Academy of Science (2004), Ogden, Williams et al. (2004), and The International Energy Agency (2005) have all envisaged transition scenarios in which hydrogen in the beginning of the transition was produced from natural gas. This is because they have assumed oil prices in the \$25-60 interval. In that interval, the competitive order is clearly that conventional fuels are most cost effective, then, natural gas based hydrogen and, then, non-combustible based hydrogen. The price level of the first half of 2008, however, gives an indications of the price level that can be expected once the world economy gets over the recessions anticipated in 2009. 
If we consider a future with oil prices on the other side of $\$ 100$ per barrel, the competitive order is totally reversed: Now Non-combustible based hydrogen is the most competitive, then natural gas based hydrogen and then conventional fuels.

Until know, the taxes have been excluded from the analysis. This does not represent a serious error when applied to the US fuel markets, but it makes the analysis very hypothetical when it comes to the costs of European consumers. All the EU countries adhere to the minimum tax of about $€ 10$ per GJ (2005€) on petrol and diesel and many of them apply tax rates about twice this minimum. High fuel taxes amplify the effect of the fuel economy on the cost per $\mathrm{km}$ and FCEVs will therefore be attractive from a cost point of view to European consumers before it will be so to US consumers (provided that the differences in taxation persist). To the consumers in a country that only charges the minimum tax of $€ 10$ per GJ on hydrogen as well as petrol and diesel, hydrogen is competitive with the conventional fuels already at $\$ 85$ per barrel for natural gas as well as non-combustible based hydrogen.

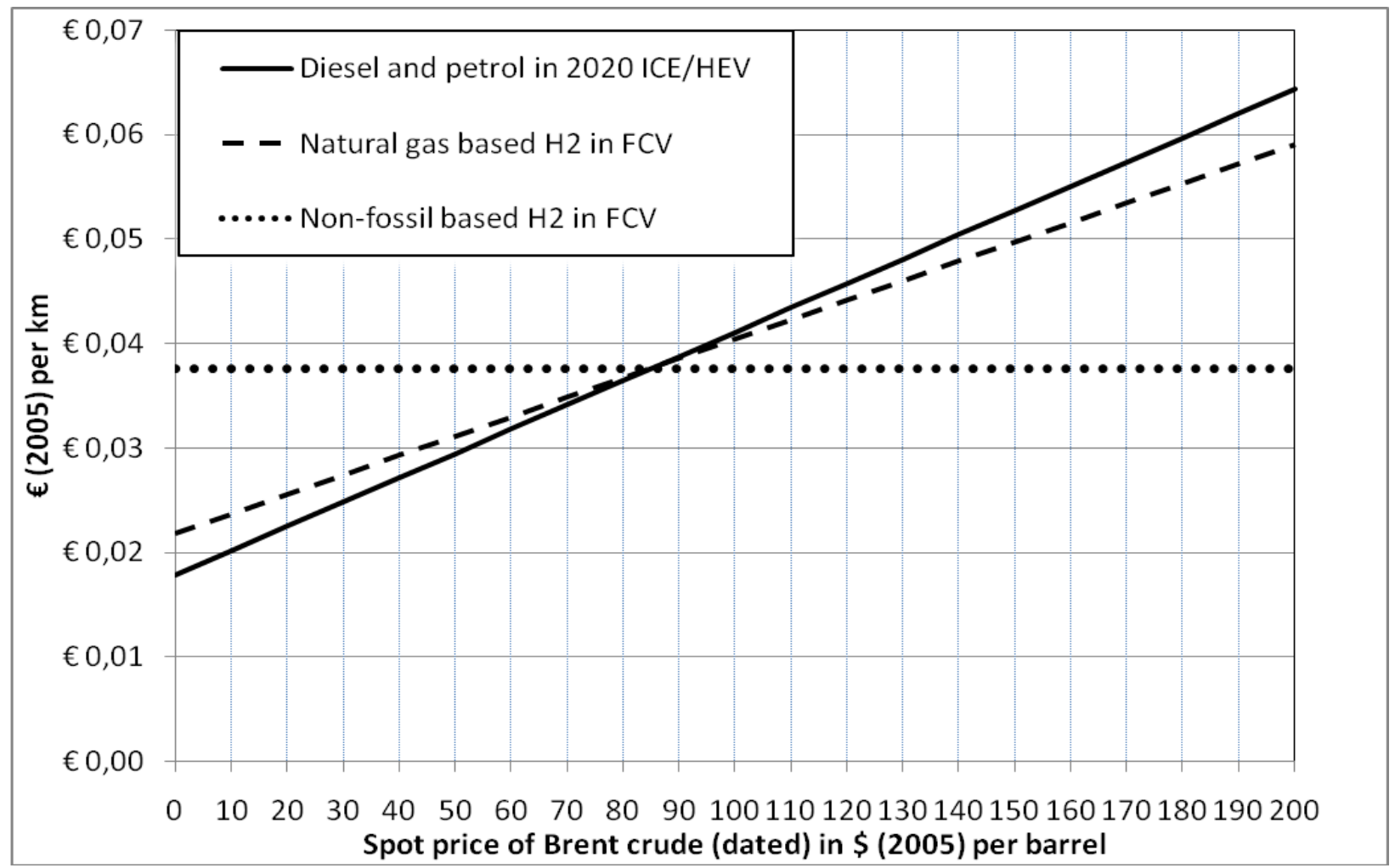

Figure 6. Per km fuel cost of ICE and FCEV technology with natural gas based and nonfossil electricity based hydrogen. Best case. Fuel taxes $€ 10 / G J$ on all fuels.

Figure 6 shows the best case scenario in a case where only the minimum rate of fuel taxation $(€ 10 / G J)$ applies. Some EU countries such as UK, Germany, and Netherlands have twice as high fuel taxes and the most countries are in between. In the worst case scenario 
with $€ 10 / G J$ fuel taxation of all fuels, non-combustible based hydrogen still becomes competitive with natural gas based hydrogen at $\$ 135$ and with non-combustible based hydrogen $\$ 150$ per barrel. This is because the high efficiency advantage of the FCEV is eaten up by the conversion losses in the hydrogen production process.

It must be anticipated that the European fuel taxes in 2015-2025 will be adjusted to provide even better incentives to contribute to the goals of the common energy policy. This will probably mean a higher level of taxation - at least in the countries that are close to the minimum taxes. It could also mean that taxes will be differentiated according to the environmental pressure, they cause per energy unit or per $\mathrm{km}$. On the other hand hydrogen involves much larger energy losses in production and distribution than petrol and diesel does, which makes a case for taxing energy losses in production as well as in use. This would deteriorate the competitiveness of hydrogen from natural gas as well as electricity, but if the tax is differentiated according to emission rates, it will be more so for natural gas.

The conclusion is that a continuing European policy of fuel taxation would be sufficient to ensure the competitiveness of the introduction of hydrogen and fuel cell technology. Moreover, the widespread belief that natural gas based hydrogen will provide the most cost effective supply in the 2020s, rests on an assumption of low oil prices that is clearly debatable.

However, the future fuel taxation policy has to take account of the much larger energy loss in the hydrogen production process than in oil refining. This has not been in the focus as long as hydrogen was a chemical, but now it becomes a fuel, it will become socially preferable that the efficiency of the entire hydrogen fuel chain is at least on the same level as the efficiency of the conventional fuel chain. Thus it is necessary to provide efficiency incentives in hydrogen production.

A simple way to do this would be to apply a production tax of the same level as the price of the emission allowance unit (EAU) at the European Emission Trading System (ETS). This can however not replace the present fuel taxes as it would be a much lower amount per GJ or per litre and therefore have the opposite effects on efficiency. A similar system would be recommendable for all industry which is not included in the ETS.

\section{The prospective contributions hydrogen and fuel cell technology}

A transition to hydrogen and fuel technology in automotive transport will be conducive to achieving the goals of energy efficiency because it makes use of the energy efficient fuel cell 
and electro-motor drive train. The size of the contribution, however, depends crucially on the system efficiency of the hydrogen production and delivery infrastructure. A tax on hydrogen feedstocks linked to the Emission Allowance Unit price on the ETS market would provide incentives for operation and equipment according to the highest efficiency standards and would prevent price distortions between the ETS sector and the non-ETS sector.

The transition will also be conducive to the goals of security of energy supply and ecoefficiency because of the more efficient use of energy. These effects are, however, rather modest in comparison with the magnitude of the changes required and the energy efficiency of other advanced solutions in the transport sector.

Replacing oil by indigenous energy sources in Europe will reduce the risk of hold-up in the throughput of oil (and gas) and reduce the bill to be paid by an oil price increase. Europe is a net-importer of all non-renewable energy resources but is relatively well endowed with renewable energy resources. The transition to hydrogen and fuel cells can help making these resources more valuable by using off-peak power that otherwise doesn't have many high value applications for a high value application like automotive mobility. In this sense it may contribute to supply security through replacing imported by indigenous primary energy.

Hydrogen produced from non-combustible fuels would contribute significantly to reducing atmospheric as well as local pollution. This would not be the case if it was made from natural gas and only partly be the case it was made from natural gas with CCS.

The cost of fuel per $\mathrm{km}$ is higher for non-combustible based hydrogen than for natural gas based hydrogen, which again is more expensive than petrol and diesel in a competing vehicle. However, this is only if the oil price in the future will be lower than $\$ 85$ per barrel. For oil prices above $\$ 85$ transport fuelled by hydrogen from non-combustible energy will be less expensive than transport fuelled by natural gas and by $\$ 105$ also less expensive than transport fuelled by diesel and petrol. In other words, the order of competitiveness will be totally reversed.

These results apply for the best case with maximum efficiency in hydrogen production. Less optimistic assumptions result in much weaker cost efficiency of hydrogen.

The high fuel taxes applied in Europe reinforce the cost effectiveness caused by the efficiency advantage of the FCEV. Thus, FCEV transport will become competitive earlier on the European market than in the US. 
In general, the contributions of the hydrogen transition to achieving the European energy policy goals depends on whether a similar transition goes on in the power and heat sector towards non-fossil energy. Indeed, a double transition is required for hydrogen and fuel cell technology to contribute significantly to the European energy and climate policy goals. Thus, the transition of the power and heat sector to non-fossil energy and of the transport sector to hydrogen will be mutually reinforcing.

\section{Literature}

Argonne National Laboratory (2008). GREET Version 1.8b. Systems Assessment Section, Centre for Transportation Research.

California Environmental Protection Agency Air Resources Board (CARB) (2008). The Zero Emission Vehicle Program - 2008.

Commission of the European Communities (2006). Green Paper: A European Strategy for Sustainable, Competitive and Secure Energy.

Commission of the European Communities (2007a). An energy policy for Europe.

Communication from the Commission to the European Coucil and the European Parliament. Commission of the European Communities (2007b). Renewable Energy Road Map. Renewable energies in the 21st century: building a more sustainable future.

Council of the European Union (2007). Presidency conclusions. Rev1, Concl1. 7224/1/07. Edwards, R., J. G. Griesemann, et al. (2007). Well-to-Wheels Analysis of Future Automotive Fuels and Powertrains in the European Context. Version $2 c$.

Energy Information Administration (EIA) US DOE (2008). International Energy Outlook 2008.

Energy Watch Group (2007). Coal: Resources and future production. Updated version: 10th July 2007.

European Commission - DG COMP (2004). Energy Sector Inquiry.

European Hydrogen \& Fuel Cell Technology Platform (HFP) (2007). Implementation PlanStatus 2006, European Hydrogen \& Fuel Cell Technology Platform (HFP).

Fuel Cell Commercialization Conference of Japan (FCCJ) (2008). Commercialization of fuel cell vehicles and hydrogen stations to commence in 2015, Fuel Cell Commercialization Conference of Japan (FCCJ).

Gerling, P., H. Rempel, et al. (2006). Reserven, Ressourcen und Verfügbarkeit von Energierohstoffen 2005. Hannover, Germany, Bundesanstalt für Geowissenschaften und Rohstoffe.

Hansen, A. C. (2007a). Hydrogen and fuel cell technology in EU LDV transport: Potential contribution to environmental goals. EECG Research Papers. Roskilde, Roskilde University, Department of Environmental, Social, and Spatial Change (ENSPAC). Hansen, A. C. (2007b). The international oil price and hydrogen competitiveness. EECG Research Papers. Roskilde, Roskilde University, Department of Environmental, Social, and Spatial Change (ENSPAC). 
Hansen, A. C. (2007c). The potential contibution of hydrogen to societal goals. EECG Research Papers. Roskilde, Roskilde University, Department of Environmental, Social, and Spatial Change (ENSPAC).

Hansen, A. C. (2007d). The supply security of hydrogen as transport fuel. EECG Research Papers. Roskilde, Roskilde University, Department of Environmental, Social, and Spatial Change (ENSPAC).

Hansen, A. C. (2007e). When will hydrogen become a competitive transport fuel? EECG

Research Papers. Roskilde, Roskilde University, Department of Environmental, Social, and Spatial Change (ENSPAC).

International Energy Agency (2005). Prospects for Hydrogen and Fuel Cells.

International Energy Agency (IEA) (2007). World Energy Outlook 2007.

OECD Nuclear Energy Agency and the International Atomic Energy Agency (IAEA)

(2008). Uranium 2007: Resources, Production and Demand.

Ogden, J. M., R. H. Williams, et al. (2004). "Societal lifecycle costs of cars with alternative fuels/engines." Energy Policy 32(1): 7-27.

Organisation for Economic Cooperation and Development (OECD) (2008). "Deploying Renewables: Principles for Effective Policies."

Panagiotidis, T. and E. Rutledge (2007). "Oil and gas markets in the UK: Evidence from a cointegrating approach." Energy Economics 29(2): 329-347.

Sorensen, B. (2005). Hydrogen and Fuel Cells. Elsevier.

Stern, J. (2007). The new security environment for European gas: Worsening geopolitics and increasing global competition for $L N G$, Oxford Institute for Energy Studies.

The Alternative Fuels Contact Group (2004). Market Development of Alternative Fuels.

The Council of the European Union (2002). State aid to the coal industry.

The CUTE Project (2008). CUTE. Detailled summary of achievements.

The European Hydrogen \& Fuel Cell Technology Platform (HFP) (2007). Implementation

Plan - Status 2006, European Hydrogen \& Fuel Cell Technology Platform (HFP).

The HyWays Project (2008). HyWays. The European Hydrogen Roadmap. FP6 Project,

Commission of the European Communities,.

US DOE, D. o. E. (2007). Hydrogen, Fuel Cells, and Infrastructure Technologies Program. Multiyear research, development, and demonstration plan. Planned program activities for 20052015. 2007 rev.

US National Academy of Science (2004). The Hydrogen Economy: Opportunities, Costs, Barriers, and RED Needs. National Academies Press.

Villar, J. A. and F. L. Joutz (2006). The Relationship Between Crude Oil and Natural Gas Prices, Energy Information Administration (EIA), Office of Oil and Gas.

World Business Council for Sustainable Development (WBCSD) and International Energy Agency (IEA) (2004). Sustainable Mobility Project Model. 